\title{
CHEMICAL COMPOSITION AND TOXICITY OF CITRUS ESSENTIAL OILS ON Dysmicoccus brevipes (HEMIPTERA: PSEUDOCOCCIDAE) ${ }^{1}$
}

\author{
GISELE DOS SANTOS OLIVEIRA MARTINS ${ }^{2 *}$, HUGO BOLSONI ZAGO ${ }^{2}$, ADILSON VIDAL COSTA ${ }^{3}$, LUIS \\ MOREIRA DE ARAUJO JUNIOR ${ }^{2}$, JOSÉ ROMÁRIO DE CARVALHO
}

\begin{abstract}
The insect Dysmicoccus brevipes (Hemiptera: Pseudococcidae) has been reported as an important pest for several crops, especially coffee. The citrus essential oils can be obtained as by-products of the citrus-processing industry and have been tested as an alternative to control different insect groups. Therefore, the objective of this work was to determine the chemical composition and evaluate the toxicity of commercial sweet orange (Citrus sinensis), bitter orange (Citrus aurantium) and Sicilian lemon (Citrus limon) essential oils and pure monoterpene D-limonene on D. brevipes. The essential oils were analyzed by gas chromatography. Two bioassays were conducted; the first assessing the insect mortality in all oils and the second assessing the lethal concentrations $\left(\mathrm{LC}_{50}\right.$ and $\left.\mathrm{LC}_{95}\right)$ of the most effective oils. The main components of the oils were D-limonene $(83.33 \%)$ and Linalool $(8.91 \%)$ (sweet orange); D-limonene (78.53\%) and $\gamma$-terpinene (12.65\%) (bitter orange); D-limonene (59.78\%), beta-pinene $(14.71 \%)$ and $\gamma$-terpinene $(10.19 \%)$ (Sicilian lemon) and the compound D-limonene had $97 \%$ of purity. The highest mortalities were found with the use of the Sicilian lemon (98.68\%) and sweet orange (94.11\%)oils. The sweet orange oil presented lethal concentrations at $2.21 \%\left(\mathrm{LC}_{50}\right)$ and $3.55 \%\left(\mathrm{LC}_{95}\right)$, and the Sicilian lemon oil at $0.72 \%\left(\mathrm{LC}_{50}\right)$ and $2.91 \%$ $\left(\mathrm{LC}_{95}\right)$. The main component of the sweet orange and Sicilian lemon essential oils was the D-limonene, and the Sicilian lemon oil was most effective oil to control $D$. brevipes.
\end{abstract}

Keywords: Cochineal. Mortality. Natural products.

\section{CARACTERIZAÇÃO QUÍMICA E TOXICIDADE DE ÓLEOS ESSENCIAIS CÍTRICOS SOBRE Dysmicoccus brevipes (HEMIPTERA: PSEUDOCOCCIDAE)}

\begin{abstract}
RESUMO - O inseto Dysmicoccus brevipes (Hemiptera: Pseudococcidae) tem sido relatado como uma praga de importância para diversas culturas, em especial a cafeicultura. Os óleos essenciais cítricos podem ser obtidos como subprodutos da indústria de sucos e vem sendo testados como alternativa no controle de diferentes grupos de insetos. Logo, objetivou-se neste trabalho determinar a composição química e avaliar a toxicidade de óleos essenciais comerciais de laranja doce (Citrus sinensis), laranja amarga (Citrus aurantium), limão Siciliano (Citrus limon) e do monoterpeno D-limoneno sobre a D. brevipes. Os óleos essenciais foram analisados por cromatografia gasosa. Foram realizados dois bioensaios. O primeiro para avaliar a mortalidade em todos os óleos e o segundo para avaliar as concentrações letais $\left(\mathrm{CL}_{50}\right.$ e $\left.\mathrm{CL}_{95}\right)$ dos óleos mais efetivos. Os constituintes majoritários do óleo de laranja doce foram o D-limoneno (83,33\%); linalol $(8,91 \%)$, do óleo de laranja amarga foram o D-limoneno $(78,53 \%)$; $\gamma$-terpineno $(12,65 \%)$, do óleo de limão Siciliano foram o D-limoneno $(59,78 \%)$; beta-pineno (14,71\%); $\gamma$-terpineno (10,19\%) e o composto D-limoneno ( $97 \%$ de pureza). O óleo de limão Siciliano e laranja doce foram os que apresentaram maior percentual de mortalidade, sendo $98,68 \%$, 94,11\%.As $\mathrm{CL}_{50}$ e $\mathrm{CL}_{95}$, para o óleo de laranja doce foram de 2,21\% e 3,55\% e para o óleo de limão Siciliano foram de $0,72 \%$ e $2,91 \%$, respectivamente. Portanto, o composto majoritário presente na composição química do óleo essencial de laranja doce e do limão Siciliano foi o D-limoneno e o mais efetivo sobre $D$. brevipes foio óleo de limão Siciliano.
\end{abstract}

Palavras-chave: Cochonilha-branca. Mortalidade. Produtos naturais.

\footnotetext{
*Corresponding author

${ }^{1}$ Received for publication in 05/04/2016; accepted in 12/05/2016.

Paper extracted from the master's dissertation of the first author.

${ }^{2}$ Department of Vegetables Production, Universidade Federal do Espírito Santo, Alegre, ES, Brazil; gisele.s.o25@hotmail.com, hugozago@gmail.com, luisjrmoreira@gmail.com,jromario_carvalho@hotmail.com.

${ }^{3}$ Department of Chemistry and Physics, Universidade Federal do Espírito Santo, Alegre, ES, Brazil; avcosta@hotmail.com.
} 


\section{INTRODUCTION}

Cochineals (Hemiptera: Coccoidea) constitute one of the main groups of insect pests in various production systems, and may infest cultivated and wild plants (SANTA-CECÍLIA, 2005). The species Dysmicoccus brevipes (Hemiptera: Pseudococcidae) has been found attacking economically important crops such as coffee and pineapple (SANTA-CECÍLIA et al., 2007; CULIK, 2008). This cochineal is a polyphagous species that infests roots, leaves and fruits of different cultures (SANTA-CECÍLIA et al., 2007).

In coffee crops, the cochineals have been causing yield losses due to injuries to the plant rosettes from flowering to harvest (SANTA-CECÍLIA et al., 2007). Infestation of coffee crops by cochineal in the State of Espírito Santo (ES), Brazil, have caused fruit dehydration and consequently yield reductions (MATIELLO; COSTA, 2010).

The method used to control insect-pests in Brazil has been predominantly the use of conventional insecticides, which can cause several problems related to their toxicity to humans, contamination of the environment and remaining residues in foods (THOMAZINI; VENDRAMIM; LOPES, 2000). Therefore, studies on alternatives to mitigate such problems are needed, such as the use of essential oils.

Essential oils are complex compounds that consist of several components, however, they are often characterized by their components of higher concentrations (BAKKALI; AVERBECK; AVERBECK, 2008). The insecticidal activity of natural products has been studied, since several plants have the potential to affect the insect behavior and metabolism, either by toxicity or repellency (SOUSA et al., 2005; BRITO; OLIVEIRA; BORTOLI, 2006).

Essential oils from plants of the genus Citrus are obtained as by-products of the citrus-processing industry. Their major component is the D-limonene, whose content vary from one species to another (BIZZO; HOVELL; REZENDE, 2009). Some researchers tested these oils as potential insecticides to control Spodoptera litura (Lepidoptera: Noctuidae), Myzuspersicae (Hemiptera: Aphididae) (ISMAN, 2000), Aedes albopictus (Diptera: Culicidae) and Musca domestica (Diptera: Muscidae) (GIATROPOULOS et al., 2012; KUMAR et al., 2012).

Therefore, the objective of this work was to determine the chemical composition and evaluate the toxicity of commercial sweet orange (Citrus sinensis), bitter orange (Citrus aurantium) and Sicilian lemon (Citrus limon) essential oils and pure monoterpene D-limonene on D. brevipes.

\section{MATERIAL AND METHODS}

The experiments were conducted in the laboratories of the Center for Agricultural Sciences of the Espírito Santo Federal University (CCA-UFES). The chemical composition of the oils was assessed at the Analytical Center and their toxicity was evaluated through bioassays at the Center for Scientific and Technological Development on Phytosanitary Management of Pests and Diseases.

\section{Origin and chemical analysis of the essential oils}

Commercial essential oils from sweet orange, bitter orange and Sicilian lemon were obtained from the citrus-processing (fruit peel) and provided by the industry Ferquima Indústria e Comércio LTDA, and the pure D-limonene ( $97 \%$ purity) was provided by the company Sigma Aldrich.

The essential oils were analyzed through gas chromatography coupled to mass spectrometry (GC-MS, QP-PLUS-2010, Shimadzu), using a fused-silica capillary chromatographic column $(30 \mathrm{~m}$ long and $0.25 \mathrm{~mm}$ of internal diameter), with stationary phase Rtx-5MS, helium as the carrier gas and temperatures of $220^{\circ} \mathrm{C}$ (injector) and $300^{\circ} \mathrm{C}$ (detector). The initial temperature of the column was $60^{\circ} \mathrm{C}$, increasing by $3^{\circ} \mathrm{C}$ every minute until reaching the maximum temperature of $240^{\circ} \mathrm{C}$ (COSTA et al., 2013).

The chemical composition of the essential oils was analyzed by gas chromatography in a GC-2010-Plus (Shimadzu) equipped with flame ionization detector (GC-FID), using a capillary column $(30 \mathrm{~m}$ long and $0.25 \mathrm{~mm}$ of internal diameter) with stationary phase Rtx-5MS, nitrogen as the carrier gas and temperatures of $240^{\circ} \mathrm{C}$ (injector) and $250^{\circ} \mathrm{C}$ (detector). The temperature of the column was the same used in the GC-MS analyzes. Samples of the oils $(10 \mathrm{mg})$ was diluted in $1 \mathrm{~mL}$ of dichloromethane, and $1 \mu \mathrm{L}$ of this solution was injected for evaluation (COSTA et al., 2013).

The components of the oils were identified by comparing the mass spectra obtained with those in the Willey 330,000 spectrographic database, and by the Kovats index (KI) calculated for each component (ADAMS, 2007).

The relative percentage of each compound was calculated by the ratio between the integral area of their respective peaks and the total area of all constituents of the sample, whose data were obtained by the gas chromatograph with flame ionization detector.

\section{Culture of D. brevipes (Cockerell, 1893) (Hemiptera: Pseudococcidae)}

The insects used in the bioassays were collected from coffee plants (Coffea canephora) in 
Alegre ES $\left(20^{\circ} 47^{\prime} 09^{\prime \prime} \mathrm{S} ; 41^{\circ} 31^{\prime} 28^{\prime \prime} \mathrm{W}\right)$ and cultivated in laboratory. The culture was maintained in the Laboratory of Entomology of the CCA-UFES in an air-conditioned room at $25 \pm 1{ }^{\circ} \mathrm{C}$, relative humidity of $70 \pm 10 \%$ and 12-hour photophase, on Japanese pumpkins (Tetsukabuto), which served as food substrate, following the methodology described by Sanches and Carvalho (2010).

\section{Bioassays}

The mortality (toxicity) of insects in the bioassays was evaluated following the methodology described by Santa-Cecília et al. (2010), using 4.5-cm-diameter leaf discs of conil on coffee leaves, arranged in 9-cm-diameter Petri dishes with 5 -mm-deep layer of a 3\% agar-water solution. Each leaf disc was infested with 15 second-instar nymphs of $D$. brevipes, and each treatment had 3 replications.

The bioassays were conducted in an air-conditioned chamber $\left(25 \pm 1^{\circ} \mathrm{C}\right.$, relative humidity of $70 \pm 10 \%$ and photophase of $12 \mathrm{~h}$ ). Evaluations were carried out at 24, 48 and 72 hours after applying the treatments to the leaf discs, by counting the dead individuals, which are characterized by a change to darker colors compared with those at the beginning of the experiment, and absence of movements.

In Bioassay I, the sweet orange, bitter orange, Sicilian lemon and pure D-limonene solutions were used at concentrations of $10 \%\left(\mathrm{v} \mathrm{v}^{-1}\right)$ to identify the most toxic products. The sweet orange and Sicilian lemon essential oils promoted the highest mortality rates (above 90\%), thus, they were subjected to concentration-mortality curves $\left(\mathrm{LC}_{50}\right.$ and $\left.\mathrm{CL}_{95}\right)$ in Bioassay II. The essential oil concentrations were $1.4,1.9,2.7,3.7$ and $5.2 \%\left(\mathrm{v} \mathrm{v}^{-1}\right)$ (sweet orange), and $1.4,1.9,3.7,5.2$ and $7.2 \%\left(\mathrm{v} \mathrm{v}^{-1}\right)$ (Sicilian lemon). The essential oil solutions were solubilized in Tween ${ }^{\circledR} 80\left(0.05 \% \mathrm{v} \mathrm{v}^{-1}\right)$ and distilled water.

The control treatment consisted of water, using the Tween ${ }^{\circledR} 80\left(0.05 \% \mathrm{v} \mathrm{v}^{-1}\right)$ as solvent. The Bioassay II was evaluatedat three periods, in order to analyze the effect of the products on different generations of the insects.

\section{Data analysis}

The Bioassay I was arranged in a completely randomized design, with means compared by the Tukey's test $(\mathrm{p} \leq 0.05)$ and mortality values corrected using the Abbott's formula (1925) in the program R Development Core Team (2009). The mortality data (number of dead insects) in Bioassay II were analyzed using the Probit regression (FINNEY, 1952), estimating the lethal concentrations $\mathrm{LC}_{50}$ and $\mathrm{CL}_{95}$. The program POLO-PC was used for the analysis, which determined the lethal concentration with a confidence interval of $95 \%$ (LEORA SOFTWORE, 1987). The curves were compared (between generations in the same oil and between oils) through confidence intervals (ROBERTSON et al., 2007).

\section{RESULTS AND DISCUSSION}

The main components of the oils were D-limonene (83.33\%) and Linalool (8.91\%) (sweet orange); D-limonene $(78.53 \%)$ and $\gamma$-terpinene (12.65\%) (bitter orange); D-limonene (59.78\%), beta-pinene $(14.71 \%)$ and $\gamma$-terpinene $(10.19 \%)$ (Sicilian lemon) (Table 1).

These results were similar, with some numerical differences, to the works of Assunção (2013) and Koketsu et al. (1983). These variations probably occur due to factors related to the oil extraction method, genetic characteristics of the species and environmental conditions in which they were grown (ASSUNÇÃO, 2013).

According to the preliminary tests in Bioassay $\mathrm{I}$, using the products at concentration of $10 \%\left(\mathrm{v} \mathrm{v}^{-1}\right)$, the Sicilian lemon (98.68\%) and sweet orange $(94.11 \%)$ essential oils and the pure D-limonene $(69.03 \%)$ presented the highest percentages of mortality. The bitter orange essential oil presented the lowest mortality rate, which did not differ from the pure D-limonene (Table 2).

Based on the results of the Bioassay I, the sweet orange and Sicilian lemon essential oils presented mortality above $90 \%$ at the concentration of $10 \%\left(\mathrm{v} \mathrm{v}^{-1}\right)$, thus, they were selected for the Bioassay II, in which the $\mathrm{LC}_{50}$ and $\mathrm{CL}_{95}$ were estimated.

The inclination of the $\mathrm{LC}_{50}$ and $\mathrm{LC}_{95}$ curves of the sweet orange and Sicilian lemon essential oils on $D$. brevipes, with their respective confidence intervals are described in Table 3 . No significant differences were found between the generations, regardless of the essential oil used.

The inclinationof the curve indicates the variability among individuals in the population (KERNS; GAYLOR, 1992). Curves with lower inclinationindicate greater genetic variability, suggesting the presence of more than one genotype in the population, i.e., a greater heterogeneity of response to the applied treatment, resulting in resistance of the population to the product used (SIQUEIRA; GUEDES; PICANÇO, 2000). The inclination of the mortality curve was higher for sweet orange oil, indicating higher mortality in small doses, compared with the curve for Sicilian lemon oil. 
G. S. O. MARTINS et al.

Table 1. Chemical composition of bitter orange (BO), sweet orange (SO) and Sicilian lemon (SL) essential oils.

\begin{tabular}{|c|c|c|c|c|c|}
\hline Constituents & KI cal & KI tab & $\mathrm{BO}$ & $\mathrm{SO}$ & SL \\
\hline \multicolumn{6}{|c|}{ Monoterpene Hydrocarbons (MH) } \\
\hline$\alpha$-thujene & 929 & 931 & $0.70 \%$ & - & $0.62 \%$ \\
\hline$\alpha$-Pinene & 935 & 939 & $2.06 \%$ & $1.08 \%$ & $2.90 \%$ \\
\hline$\beta$-Pinene & 976 & 980 & $1.57 \%$ & - & $14.71 \%$ \\
\hline Myrcene & 992 & 991 & $1.28 \%$ & $3.60 \%$ & $0.54 \%$ \\
\hline$\alpha$-Terpinene & 1016 & 1018 & $0.35 \%$ & - & $0.22 \%$ \\
\hline D-D-limonene & 1033 & 1031 & $78.53 \%$ & $83.33 \%$ & $59.78 \%$ \\
\hline$\gamma$-Terpinene & 1061 & 1062 & $12.65 \%$ & - & $10.19 \%$ \\
\hline Terpinoline & 1089 & 1088 & $0.78 \%$ & - & $0.66 \%$ \\
\hline Canphene & 950 & 953 & - & - & $0.11 \%$ \\
\hline cis-ocimene & 1042 & 1040 & - & - & $0.08 \%$ \\
\hline trans-ocimene & 1052 & 1050 & - & - & $0.16 \%$ \\
\hline Sabinene & 974 & 980 & - & $1.02 \%$ & - \\
\hline \multicolumn{6}{|c|}{ Oxygenated Monoterpenes (OM) } \\
\hline trans- $\beta$-terpineol & 1165 & 1163 & - & $0.14 \%$ & - \\
\hline Terpin-4-ol & 1176 & 1177 & - & - & $0.20 \%$ \\
\hline$\alpha$-terpineol & 1189 & 1189 & $0.41 \%$ & - & $0.58 \%$ \\
\hline Linalol & 1099 & 1098 & $0.35 \%$ & $8.91 \%$ & $0.26 \%$ \\
\hline n-octanal & 1000 & 1001 & $0.12 \%$ & - & $0.12 \%$ \\
\hline Cis- para-menth-2-em-1-ol & 1121 & 1121 & $0.06 \%$ & - & - \\
\hline Cis-D-limonene-oxide & 1134 & 1134 & $0.14 \%$ & $0.18 \%$ & $0.30 \%$ \\
\hline trans-D-limonene- oxide & 1139 & 1139 & - & $0.16 \%$ & $0.26 \%$ \\
\hline Citronellal & 1155 & 1153 & - & $0.08 \%$ & - \\
\hline n-decanal & 1204 & 1204 & $0.18 \%$ & $0.62 \%$ & - \\
\hline Geranial & 1272 & 1270 & - & $0.21 \%$ & 2.18 \\
\hline Neral & 1242 & 1240 & - & - & $1.45 \%$ \\
\hline \multicolumn{6}{|c|}{ Sesquiterpene Hydrocarbons (SH) } \\
\hline trans-caryophillene & 1417 & 1418 & $0.18 \%$ & - & $0.38 \%$ \\
\hline$\beta$-bisabolene & 1507 & 1509 & - & - & $1.66 \%$ \\
\hline$\alpha$-Copaene & 1367 & 1376 & - & $0.10 \%$ & - \\
\hline \multicolumn{6}{|c|}{ Oxygenated Sesquiterpenes (OS) } \\
\hline n-decanal & 1205 & 1204 & $0.18 \%$ & $0.62 \%$ & - \\
\hline Geranyl acetate & 1384 & 1383 & $0.39 \%$ & - & $0.64 \%$ \\
\hline trans-nerolidol & 1563 & 1564 & $0.25 \%$ & - & - \\
\hline n-octanol & 1075 & 1070 & - & $0.57 \%$ & - \\
\hline neryl acetate & 1366 & 1365 & - & - & $0.99 \%$ \\
\hline$\alpha-$ trans-Bergamotene & 1435 & 1436 & - & - & $1.01 \%$ \\
\hline $\mathrm{MH} / \mathrm{OM}$ & - & - & $97.92 / 1.26$ & $89.03 / 10.3$ & $89.97 / 5.35$ \\
\hline $\mathrm{HS} / \mathrm{OS}$ & - & - & $0.18 / 0.64$ & $0.10 / 0.57$ & $2.04 / 2.64$ \\
\hline
\end{tabular}

$\mathrm{KI}$ cal $=$ Kovats index calculated, $\mathrm{KI}$ tab $=$ Kovats index tabled $($ ADAMS, 2007).

Table 2. Mean mortality rate of Dysmicoccus brevipes treated with different citrus essential oils at $10 \%$ concentration $\left(\mathrm{v} \mathrm{v}^{-1}\right)$ (temperature of $25 \pm 1^{\circ} \mathrm{C}$, relative humidity of $70 \pm 10 \%$ and photophase of $12 \mathrm{~h}$ ).

\begin{tabular}{cc}
\hline Treatments & Corrected Mortality \\
\hline Sweet orange essential oil & $94.11 \pm 2.39 \mathrm{a}$ \\
Bitter orange essential oil & $48.52 \pm 6.21 \mathrm{~b}$ \\
Sicilian lemon essential oil & $98.68 \pm 1.31 \mathrm{a}$ \\
Pure D-limonene & $69.03 \pm 9.84 \mathrm{ab}$ \\
\hline Coefficient of variation(\%) & 21.72 \\
\hline
\end{tabular}

Means followed by the same letter did not significantly differ by the Tukey's test at $5 \%$ probability. Mortality corrected by the Abbott's formula.

The treatment with Sicilian lemon essential oil presented a more heterogeneous D. brevipes population compared with the treatment with sweet orange essential oil. This variability among individuals of the same population is denoted by the inclination of the concentration-mortality curve
(KERNS; GAYLOR, 1992). This result indicates an intra-populational genetic diversity or different selective pressures on the individuals, which contribute to the development of insect resistance in the case of continuous use of these oils, and may explain the variability obtained in these results. 
G. S. O. MARTINS et al.

Table 3. Inclination of curves of lethal concentrations $\left(\mathrm{LC}_{50}\right.$ and $\left.\mathrm{LC}_{95}\right)$ of sweet orange and Sicilian lemon essential oils to Dysmicoccus brevipes(Temperature $25 \pm 1{ }^{\circ} \mathrm{C}$, relative humidity of $70 \pm 10 \%$ and photophase of $12 \mathrm{~h}$ ).

\begin{tabular}{|c|c|c|c|c|c|c|}
\hline Oils & Generation & $\mathrm{N}$ & Inclination $\pm \mathrm{SE}$ & $\mathrm{LC}_{50}(\%)(\mathrm{CI} 95)$ & $\mathrm{LC}_{95}(\%)(\mathrm{CI} 95)$ & $\chi^{2}$ \\
\hline \multirow{3}{*}{$\begin{array}{l}\text { Sweet } \\
\text { orange }\end{array}$} & 1 & 247 & $4.81 \pm 0.72$ & $2.11(1.87-2.32)$ & $4.64(3.92-6.22)$ & $1.88^{\mathrm{ns}}$ \\
\hline & 2 & 281 & $5.77 \pm 0.64$ & $2.47(2.29-2.65)$ & $4.76(4.21-5.74)$ & $2.11^{\mathrm{ns}}$ \\
\hline & 3 & 267 & $5.72 \pm 0.57$ & $2.26(2.09-2.42)$ & $4.39(3.96-5.08)$ & $5.64^{\mathrm{ns}}$ \\
\hline \multirow{2}{*}{\multicolumn{2}{|c|}{$\mathbf{z}-\mathbf{-}-\mathbf{-}-\mathbf{-} \frac{\text { Total }}{1}$}} & 795 & $6.22 \pm 0.51$ & $2.21(2.12-2.30)$ & $4.43(3.64-6.80)$ & $5.75^{\mathrm{ns}}$ \\
\hline & & 202 & $2.09 \pm 0.40$ & $0.78(0.38-1.12)$ & $2.78(1.64-3.61)$ & $3.59^{\mathrm{ns}}$ \\
\hline \multirow{3}{*}{$\begin{array}{l}\text { Sicilian } \\
\text { lemon }\end{array}$} & 2 & 234 & $3.82 \pm 1.06$ & $0.80(0.40-0.98)$ & $2.35(2.02-3.91)$ & $2.91^{\mathrm{ns}}$ \\
\hline & 3 & 199 & $2.78 \pm 0.53$ & $0.68(0.45-0.88)$ & $2.99(2.01-4.12)$ & $4.90^{\mathrm{ns}}$ \\
\hline & Total & 635 & $2.11 \pm 0.36$ & $0.72(0.47-0.97)$ & $2.91(2.42-3.40)$ & $2.77^{\mathrm{ns}}$ \\
\hline
\end{tabular}

$\mathrm{N}=$ number of individuals of the sampled population; Inclination $\pm \mathrm{SE}=$ inclination of the curve \pm standard error; $\mathrm{LC}_{50}=$ Lethal Concentration to $50 \%$ of the sample population; $\mathrm{LC}_{95}=$ Lethal Concentration to $95 \%$ of the sample population; CI95 = Confidence interval of the LC at $95 \%$ of probability; $\chi^{2}=$ Chi-square test.

The Sicilian lemon oil was more toxic to $D$. brevipes than the sweet orange oil because its lower lethal concentration $\left(\mathrm{LC}_{50}\right.$ of $0.72 \%$ and $\mathrm{LC}_{90}$ of $2.91 \%)$. Most of the insecticidal capacity of citrus essential oils are due to the substances D-limonene and Linalool, which have contact (degrade exoskeleton cuticle lipids) and fumigant actions against insects (BUSS; PARK-BROWN, 2002; ROZMAN; KALINOVIC; KORUNIC, 2007).

The insecticidal activityof the pure D-limonene (at $10 \%$ of the solution) was evaluated because it is the most common compound in the essential oils tested, however, when applied singly, it caused mortalities below $90 \%$, denoting that the bioactivity of the essential oils is usually due to the major constituents.

However, the bioactivity may also be affected by minor constituents, which may promote a synergism with the major constituents, thus increasing mortality (JIANG et al., 2009). The interactions between major and minor constituents are complex and may affect the characteristics of the essential oil, as well as the deleterious effects on insects.

The greater insecticidal activity of the Sicilian lemon and sweet orange essential oils, compared with the pure D-limonene, was probably due to the synergy of their compounds. Moreover, the complexinteractions between components of essential oils can change the physiology of insects (KHALFI et al., 2008; RATTAN, 2010).

Therefore, the Sicilian lemon (Citrus limon) and sweet orange (Citrus sinensis) essential oils showed insecticidal activity on $D$. brevipes, which can be attributed to interactions between major and minor constituents, since the chemical compounds are very important for the insecticidal activity, regardless of their concentration in the essential oil.

\section{CONCLUSION}

The major compound present in the chemical composition of the sweet orange (Citrus sinensis), bitter orange (Citrus aurantium) and Sicilian lemon (Citrus limon) essential oils was the D-limonene. The Sicilian lemon essential oil promoted the highest mortality rates of $D$. brevipes with a lower lethal concentration and thus, it was the most effective for controlling this insect.

\section{ACKNOWLEDGMENTS}

The authors thank to the institutions NUDEMAFI, CAPES and FAPES for technical and financial support.

\section{REFERENCES}

ABBOTT, W. S. A method for computing the effectiveness of an insecticide. Journal of Economic Entomology, Oxford, v. 18, n. 1, p. 265-267, 1925.

ADAMS, R. P. Identification of essential oil components by gas chromatography mass spectroscopy. 4. ed. Carol Stream: Allured Publishing Corp, 2007. 804 p.

ASSUNÇÃO, G. V. Caracterização química e avaliação da atividade larvicida frente ao Aedes aegypti do óleo essencial da espécie Citrus sinensis L. Osbeck (laranja doce). 2013. 93 f. Dissertação (Mestrado em Química: Área de Concentração em Química de Produtos Naturais e Alimentos) - Universidade Federal do Maranhão, São Luís, 2013. 
BAKKALI, F.; AVERBECK, S.; AVERBECK, D. Biological effectis of essential oils. Food and Chemical Toxilology, Oxford, v. 46, n. 2, p. 446-475, 2008.

BIZZO, H. R.; HOVELL, A. M.; REZENDE, C. M. Óleos essenciais no Brasil: aspectos gerais, desenvolvimento e perspectivas. Química Nova, São Paulo, v. 32, n. 3, p. 588-594, 2009.

BRITO, J. P.; OLIVEIRA, J. E. M.; BORTOLI, S. A. Toxicidade de óleos essenciais de Eucalyptus spp. Sobre Callosobruchus maculatus (Fabr. 1775) (Coleoptera: Bruchidae). Revista de Biologia e Ciência da Terra, São Cristóvão, v. 6, n. 1, p. 96-103, 2006.

BUSS, E. A.; PARK-BROWN, S. G. Natural products for insect pest management. Gainesville: UF/IFAS, 2002. Disponível em: <http:// edis.ifas.ufl.edu/IN197>. Acesso em: 06 ago. 2015.

COSTA, A. V. et al. Cymbopogon citratus (Poaceae) essential oil on Frankliniella schultzei (Thysanoptera: Thripidae) AND Myzus persicae (Hemiptera: Aphididae). Bioscience Journal, Uberlândia, v. 29, n. 6, p. 1840-1847, 2013.

CULIK, M. P. et al. Diaspididae (Hemiptera: Coccoidea) of Espírito Santo, Brazil. Journal of Insect Science, Tucson, v. 8, n. 17, p. 1-6, 2008.

FINNEY, D. J. Probit Analysis: a statistical treatment of the sigmoid response curve. 2. ed. New York-London: Cambridge University Press, 1952. $318 \mathrm{p}$.

GIATROPOULOS, A. et al. Evaluation of bioefficacy of three Citrus essential oils against the dengue vector Aedes albopictus (Diptera: Culicidae) in correlation to their components enantiomeric distribution. Parasitology Research, Berlin, v. 111, n. 6, p. 2253-2263, 2012.

ISMAN, M. B. Plant essential oils for pest and disease management. Crop Protection, Guildford, v. 19, n. 1, p. 603-608, 2000.

JIANG, Z. et al. Comparative toxicity of essential oils of Litseapungens and Litseacubeba and blends of their major constituents against the cabbage looper, Trichoplusiani. Journal of Agricultural and Food Chemistry, Washington, v. 57, n. 1, p. 4833-4837, 2009.

KERNS, D. L.; GAYLOR, M. J. Insecticide resistance in field populations of the cotton aphid (Hemiptera: Aphididae). Journal of Economic Entomology, Oxford, v. 85, n. 1, p. 1-8, 1992.
KHALFI, O. et al. Chemical composition and insecticidal properties of Origanumglandulosum (Desf.) essential oil from Algeria. Journal Science of Food and Agriculture, New York, v. 88, n. 1, p. 1562-1566, 2008.

KOKETSU, M. et al. Óleos Essenciais de Frutos Cítricos Cultivados no Brasil. Rio de Janeiro: Embrapa, 1983. v. 7, 21 p. (Boletim de Pesquisa).

KUMAR, P. et al. Insecticidal evaluation of essential oils of Citrus sinensis L. (Myrtales: Myrtaceae) against housefly, Muscadomestica L. (Diptera: Muscidae). Parasitology research, Berlin, v. 110, n. 5, p. 1929-1936, 2012.

LEORA SOFTWARE. POLO-PC: An user's guide to probit or logit analysis. Berkeley, CA: Leora Software, 1987. $22 \mathrm{p}$.

MATIELlO, J. B.; COSTA, F. F. Coró das pastagens "ataca" em cafezais: surto de cochonilha da roseta do cafeeiro no Espírito Santo. Revista Brasileira de Tecnologia Cafeeira, Varginha, v. 6, n. 17, p. $30-32,2010$.

RATTAN, R. S. Mechanism of action of insecticidal secondary matabolites of plant origin. Crop Protection, New York, v. 29, n. 9, p. 913-920, 2010.

R DEVELOPMENT CORE TEAM. R: A language and environment for statistical computing. $\quad \mathbf{R}$ Foundation for Statistical Computing, Vienna, 2009. Disponível em: <http:// www.Rproject.org>.Acesso em: 09 nov. 2015.

ROBERTSON, J. L. et al. Bioassays with Arthropods. 2. ed. Boca Raton: CRC Press, 2007. $199 \mathrm{p}$.

ROZMAN, V.; KALINOVIC, I.; KORUNIC, Z. Toxicity of naturally occurring compounds of Lamiaceae and Lauraceae to three stored-products insects. Journal of Stored Products Research, Oxford, v. 43, n. 1, p. 349-355, 2007.

SANCHES, N. F.; CARVALHO, R. S. Procedimentos para manejo da criação e multiplicação do predador exótico Cryptolaemus montrouzieri. Cruz das Almas: Embrapa Mandioca e Fruticultura, 2010. p. 1-5. (Circular Técnica, 99).

SANTA-CECÍLIA, L. V. C. et al Cochonilhas - farinhentas em cafeeiros: bioecologia, danos e métodos de controle. Belo Horizonte: EPAMIG, 2007. 48 p. (Boletim Técnico, 79).

SANTA-CECÍLIA, L. V. C. et al. Extratos de plantas no controle de Planococcus citri (Risso, 
1813) (Hemiptera: Pseudococcidae) em cafeeiro.

Coffee Science, Lavras, v. 5, n. 3, p. 283-293, 2010.

SANTA-CECÍlIA, L. V. C.; SOUZA, B. Controle biológico de cochonilhas-farinhenta sem cultivos protegidos. Belo Horizonte: EPAMIG, 2005. v. 26, n. 225, p. 24-30 (Informe Agropecuário).

SOUSA, A. H. et al. Bioactivity of vegetal powders against Callosobruchus maculatus (Coleoptera: Bruchidae) in caupi bean and seed physiological analysis. Revista de Biologia e Ciências da Terra, Campina Grande, v. 5, n. 2, p. 1-6, 2005.

SIQUEIRA, H. A. A.; GUEDES, R. N. C.; PICANÇO, M. C. Insecticide resistance in populations of Tuta absoluta (Lepdoptera: Gelechiidae). Agricultural and Forest Entomology, St Albans, v. 2, n. 2, p. 147-153, 2000.

THOMAZINI, A. P. B. W.; VENDRAMIM, J. D.; LOPES, M. T. R. Extratos aquosos de Trichilia pallida e a traça-do-tomateiro. Scientia Agrícola, São Paulo, v. 57, n. 1, p. 13-17, 2000. 